\title{
Analysing the Efficiency of Managing the Rural Social Infrastructure in the Region
}

Shynar Isabekovna Kossymbayeva, ${ }^{+*}$ Anar Zhaskairatovna Nukesheva, ${ }^{\dagger}$ Laila Gabitovna Kirbassova, ${ }^{¥}$ and Bibigul Suleimenovna Saubetova ${ }^{*}$

\section{Abstract}

The article aims to summarise theoretical conclusions and practical results of studying the activities of local bodies on managing the development of rural social infrastructure in the Republic of Kazakhstan. In the article, the objective and subjective indicators characterising the efficiency of managing the rural social infrastructure in rural areas of the Mangystau Region for 2013-2017 have been analysed. Through the example of a statistical study of the dynamics of the social infrastructure elements and living standards, the features and problems related to the administrative measures that regulate the socio-economic development of auls in the region have been identified. Using the questionnaire survey, the satisfaction of rural residents in the Mangystau Region with the quality of their social infrastructure has been determined. It has been proved that now the subjective assessment of the efficiency of managing the rural social infrastructure is positively correlated (correlated) with the degree of efforts taken by the local administration to improve the quality of rural life. Currently, rural settlements of the Mangystau Region have an average level of social infrastructure development. However, in different areas, the level of residents' satisfaction with it varies from very low to sufficient.

Keywords: Social Infrastructure; Quality of Life; Management; Rural Areas; Population; Mangystau Region; Republic of Kazakhstan region

\footnotetext{
${ }^{\dagger}$ S. Seifullin Kazakh Agro Technical University, Zhenis avenue, 62, Astana, 010011, Kazakhstan

${ }^{*}$ Corresponding Author, Email: honeyzhu@mail.ru

¥ Yessenov University, Aktau 32 Micro District, 130000, Kazakhstan

(C) 2019 Kossymbayeva et al. This is an Open Access article distributed under the terms of the Creative Commons Attribution License (http://creativecommons.org/licenses/by/2.0), which permits unrestricted use, distribution, and reproduction in any medium, provided the original work is properly cited.
} 


\section{Introduction}

It is extremely important to study the issues on managing the village social infrastructure (hereinafter - the VSI) due to the problem on achieving its residents' well-being that is directly related to the quality of life of the population of any country.

The social infrastructure is a multidimensional phenomenon. Therefore, it would be wrong to assess it based on only one opinion.

It can be argued that the VSI is a comprehensive regional complex that includes a rural territory economically equipped for the life of people, organisations and institutions of the social and services sectors, as well as governing bodies ensuring the social well-being of the population working and living in this rural area.

In the most general form, the social infrastructure is the material and technical base for the social sectors of the society to fulfil their socially essential functions (Komarov, 2000).

According to the territorial belonging, the social infrastructure can be state (macroeconomic), regional (for example, provincial level), and local (local - regional, urban, rural, and corporate) (Nukesheva, 2001).

The sustainable development of rural areas is impossible without constant attention to the VSI management, by which we understand the process of targeted, external influence on rural social infrastructure facilities, designed to ensure the achievement of a particularly beneficial effect.

On the one hand, theoretical and empirical importance of the issues on the efficient VSI management has become relevant due to the considerable growth of certain negative phenomena- rural poverty and the crises in the agrarian production. The current global challenge to rural development is the need to create and diversify management of rural areas, to reduce inequality, and to improve the access of rural residents to the infrastructure.
On the other hand, the relevance of VSI studies is determined by the urgent tasks of governmental management in rural regions. It is known that in order to solve the problems linked to poverty and agrarian crises, many countries of the world develop special program documents and attract considerable financial resources (Bulkhairova et al., 2018).

Currently, there are numerous programs in the United States. They aim at supporting rural development, including Initiatives to Develop New Markets, Sustainably Developing Rural Communities. The PRC uses the system of "open territories", and EU countries, amongst others, apply regional programs aimed at enhancing the competitiveness of rural areas, involving local assets and nontraditional resources. (Serkov et al., 2018). At the same time, "the evidence from practice shows that the purposeful and comprehensive development of rural areas, including the formation of an adequate social infrastructure, contributes to implementing the labour potential of the people employed in the industry, and, therefore, it is one of the determining factors for the efficient operation of agricultural production" (Kozlov et al., 2018: 34).

In Kazakhstan, the interest in studying the issues on managing VSI has considerably increased over the recent decade due to the implementation of governmental programsDevelopment of Rural Territories of the Republic of Kazakhstan for 2004 - 2010; Development of Regions for 2012 - 2020; Infrastructure Development Nurly Zhol for 2015 - 2019; Nurly Kosh, Agrobusiness-2021; and the development of the General scheme to organise the territory (hereinafter referred to as the GOST) of the Republic of Kazakhstan (31.12.2013) (GOST, 2013); the adoption of Law of the Republic of Kazakhstan No. 73-VI On State Regulation of Developing the Agro-Industrial Complex and Rural Territories dated 15.06.2017 and the Auylbesigi program.

The hypothesis of this study is the assumption that the statistical indicators of the VSI development directly depend on the efficient management system, and the subjective 
assessments of the population's satisfaction with their life quality are weakly related to the results of the work performed by management bodies.

The object of this study is the social infrastructure of the Mangystau Region of the Republic of Kazakhstan as a part of the system on providing a high life quality and an indicator of managing the social and labour area of the rural economy.

This research aims at preliminary assessing of the efficiency of the rural social infrastructure management in the Mangystau Region.

The article begins with a brief description of a review of scientific publications followed by a description of the research methodology. The final sections discusses the results of the statistical analysis and questionnaire used among the rural population of the Mangystau Region.

\section{Literature Review}

As an independent theoretical and practical problem, the social infrastructure has been studied in theories of the post-industrial society since the mid-1950s. Since the beginning of the 21st Century, science has accumulated a significant number of studies concerning infrastructure problems of village social infrastructure (VSI), especially in the context of sustainable rural development.

Following the opinion of such researchers as (Esimova, 2010; Susura, 2012; Stukach, 2015; Kleimenov, 2016), the VSI management will be interpreted as activities on exercising legal, executive and other powers of the state in order to fulfil its organisational and administrative and economic functions in the social area of the rural community. The main regulatory functions of the VSI management include stabilisation, resource allocation and compliance with social standards. It is proper to consider the VSI management in the region as "a specific set of management actions and management process that integrates and coordinates all areas of the rural population's life by creating favourable conditions for increasing the economic potential, improving the infrastructure of the territory, developing local self-government and rational environmental management in order to adequately meet the needs of the present and future generations" (Balandin, 2014: 168).

Based on this definition, the efficiency of the VSI management is, first of all, a positive quantitative assessment of the direct results of the administrative activities performed by the bodies and services that are responsible for implementing the tasks on developing the material and technical basis of the social area, as well as the labour market and employment in rural areas. In this case, there is an economic effect of the VSI management expressed in numerical values.

At the same time, "the management is a stimulating element of social changes and an example of considerable social changes" (Drucker, 1987: 18). The modern society has moved to a new stage of sustainable development called "the life quality civilisation" (Diterich, \& Merzlov, 2013: 5 ) when such indicators as demography, welfare and living standards rather than the quantitative economic growth are becoming more and more critical. Life quality becomes the main goal of social development and a symbol of its progress (Bulkhairova et al., 2018). Because of these reasons, we argue that the efficiency of the VSI management should be assessed not only by quantitative (statistical), but also qualitative (social) indicators.

In Kazakhstan, the problems of managing social facilities in rural areas were first considered by G.K. Kassenov, who emphasised the negative consequences of VSI degradation in rural areas of the country. The scholar wrote that "against the general background of the economic growth, there was a growing disproportion in the living standard of the urban and rural population, and considerable regional difference in income. The further maintenance of this state ... affects the socio-political atmosphere of the society and has a negative impact on the human development indicators and the country's investment image" (Kasenov, 2004: 131).

In light of these backdrops, the article aims to analyse the efficiency of managing the rural 
social infrastructure of the study region. The novelty of the study is in the relative simplicity of the applied methodology that provides rather extensive factual material to make the preliminary conclusions.

\section{Materials and Methods}

In this article, we deployed well-known research methods, including (a) content analysis of the existing modern sources on developing the VSI, (b) data systematisation, comparative and logical analysis, generalisation, (c) statistical analysis of the social indicators dynamics, and (d) empirical research by using a survey method.

Particular methods of the economic study included the questioning and focus group method, economic and statistical grouping, comparative method, methods of expert assessments, analogies, mathematical statistics, economic and mathematical. The content analysis has shown that references offer a lot of various recommendations, methodologies, criteria and indicators that make it possible to assess the VSI. In a number of cases, they are all systematised. At the same time, the social infrastructure is studied as an object and as an integral set of its subsystems, elements and the whole variety of the revealed properties and connections within the object. For example, a method is presented for calculating a composite indicator on developing the social infrastructure branches as the arithmetic average ( $\Sigma \mathrm{VSI}$ ) of education and health care services (Alashbaeva, 2013).

The following surveys were carried out: a quantitative study of the territorial location of villages in the Mangystau Region, their demographic situation (the size, composition, and age of the population, regional net migration), indicators of the economic development (employment and the labour market, poverty, living conditions of the population; educational and medical institutions, etc).

The respective socio-economic indicators for each rural populated area (production growth indices, wages and unemployment rates, the volume of capital investments in the social area, the cost of the consumer basket, housing, and social and housing infrastructure) have been calculated.

During the empirical research, the information on the quality of the rural social infrastructure development in the Mangystau Region, on the satisfaction of the local population with their condition, and on the efficiency of the current system of managing the sustainable development in rural areas has been collected and interpreted by carrying out oral and written surveys and mandatory recording of the data on paper and sound carriers. Upon completing the survey, the information was processed by using standard methods of statistical analysis by ranking the results according to their importance and determining their optimal values.

\section{Results}

Before analysing the results, we present the effectiveness of VSI management as shown in Figure 1. The Mangystau Region (hereinafter referred to as the MR) is one of the three western regions of the Republic of Kazakhstan. It occupies an area of 165.6 thousand sq. km. predominantly in the desert natural zone, that is, where there are partially unfavourable conditions for the population settlement (GOST, 2013).

Administratively, the MR includes two cities (Aktau and Zhanaozen), five districts that consist of 42 rural regional districts (hereinafter referred to as RD), comprising 66 rural settlements (hereinafter referred to as RS) (Table 1). 


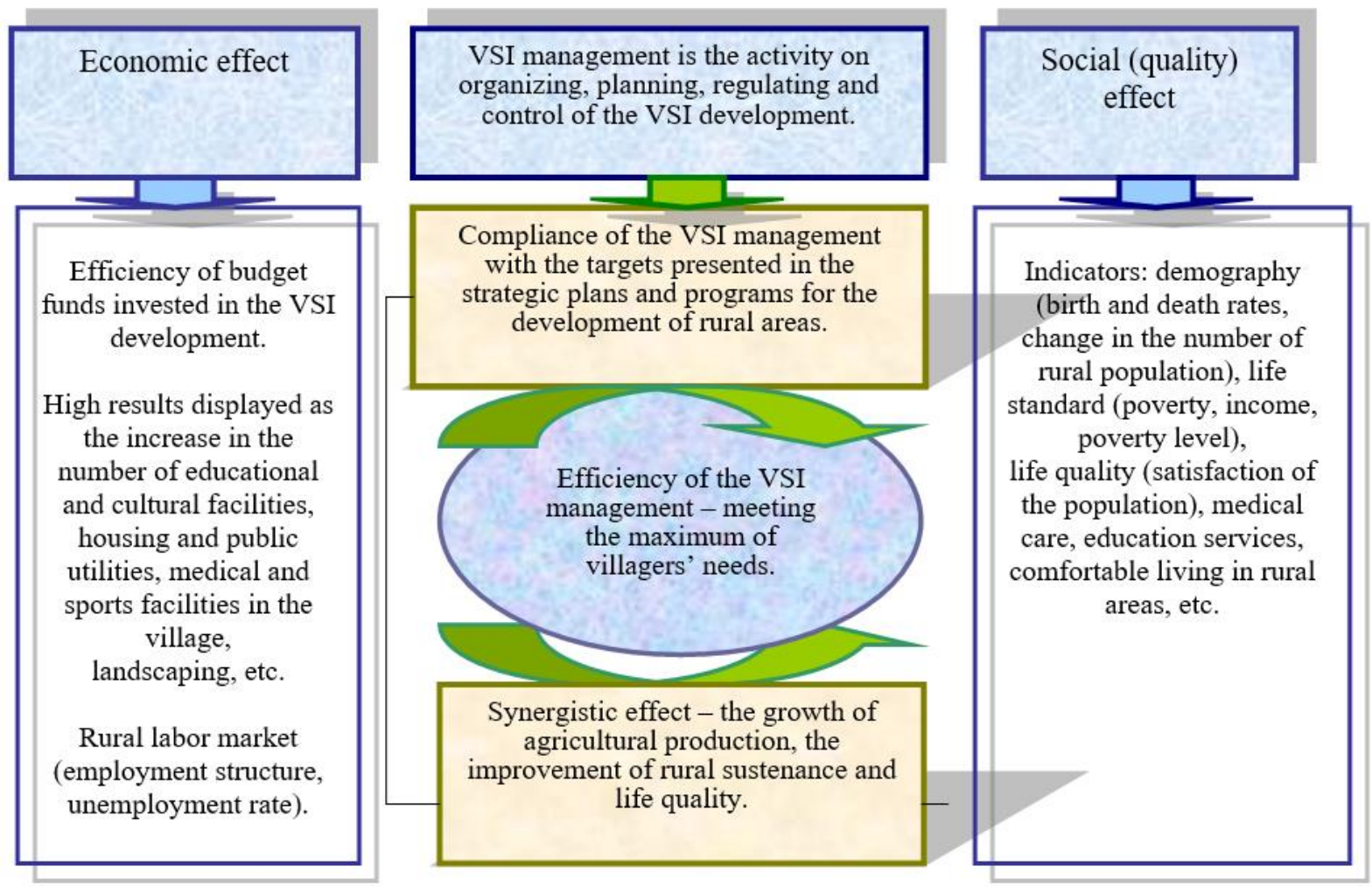

Figure 1: Main Components of the Efficiency of Managing the Village Social Infrastructure Source: Compiled by the Authors

\begin{tabular}{|c|c|c|c|c|c|c|c|c|}
\hline & 1 & 2 & 3 & 4 & 5 & 6 & 7 & $\begin{array}{l}\text { MR, } \\
\text { Total }\end{array}$ \\
\hline $\begin{array}{l}\text { 1.Territory (sq. } \\
\mathrm{km} \text { ) }\end{array}$ & 78.48 & 51.5 & 40,519 & 64,292 & 47,018 & 4,922 & 8,520 & 165,642 \\
\hline $\begin{array}{l}\text { 2. Number of } \\
\text { RDs (units) }\end{array}$ & - & - & 11 & 7 & 12 & 7 & 5 & 42 \\
\hline $\begin{array}{l}\text { 3. Number of } \\
\text { RS(units) }\end{array}$ & - & - & 11 & 12 & 23 & 11 & 9 & 66 \\
\hline $\begin{array}{l}\text { 4. Share of } \mathrm{CHC} \\
\text { with respect to } \\
\text { total number, } \\
\text { (\%) }\end{array}$ & - & - & 16.6 & 18.2 & 35 & 16.6 & 13.6 & 100 \\
\hline 5. Population & 186,353 & 147,962 & 68,285 & 37,183 & 38,553 & 152,666 & 29,260 & 660,262 \\
\hline $\begin{array}{l}\text { 6. Date of } \\
\text { Establishment }\end{array}$ & 1963 & 1964 & 1973 & 1973 & 1928 & 2007 & 1992 & 1973 \\
\hline \multicolumn{9}{|c|}{$\begin{array}{l}\text { * Hereinafter, the numbers in the column headings of the table indicate: } \\
1 \text { - Aktau, } 2 \text { - Zhanaozen, } 3 \text { - Beyneu Region, } 4 \text { - Karakiya Region, } 5 \text { - Mangystau Region, } \\
6 \text { - Munaily Region, } 7 \text { - Tupkaragan Region. () } \\
\text { Source: Compiled by the Authors Based on Kazakhstan in 2017, Monitoring the aul (village) } \\
\text { development, } 2018\end{array}$} \\
\hline
\end{tabular}

According to Table 1, more than half (51\%) of the total population of the MR live in two cities (334.3 thousand people). The Munaily Area, which is the youngest, is the largest in terms of the number of residents (152.6 thousand people, or $23 \%$ of the total population of the 
MR). At the same time, it occupies the smallest area $(4,922 \mathrm{sq} . \mathrm{km}$, or three per cent of the entire territory of the MR). In this area, there are seven RD and twelve RS.

The largest number of RD (12 out of 42) and RS (19 villages and four auls, or $35 \%$ of the regional total) are located in the Mangystau Area, which is the second largest and the oldest ones in the region. Its administrative centre is the village of Shetpe. In terms of the population, this region is the fourth among the administrative units of the MR. About $6 \%$ of the region's population live here.
According to the official statistics, $100 \%$ of the population of the four areas of the MR - Beineu, Karakiyan, Mangystau and Munaily - are referred to as rural. Approximately, $79 \%$ of the population of the Tupkaragan area, whose administrative centre is the city of FortShevchenko, is rural. Besides, $45 \%$ of the population from Zhanaozen and nearly $2 \%$ of the population from Aktau are also rural. Figure 2 shows the dynamics of the rural population by areas.

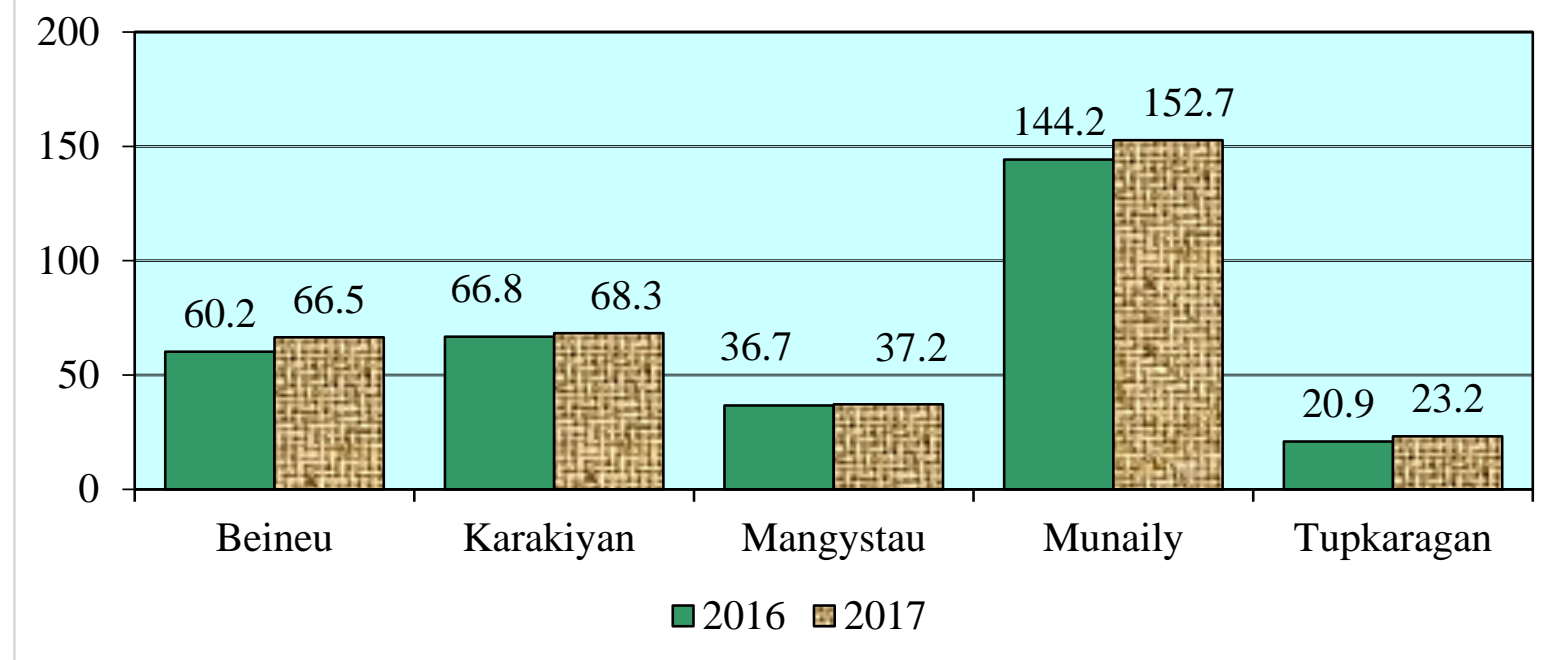

Figure 2: The Number of Rural Population in the MR, thousand people Source: Compiled by the Authors

The peculiarities of the population's settlement in the region are due to its sharply continental, arid climate and the fact that only the Caspian Sea (the seaports of Aktau, Bautino and Kuryk) and 33 groundwater fields belong to the region's water resources. The Ustyurt Plateau where the $M R$ is located has extensive hydrocarbon reserves, which initially determined the region's single-source oil and gas economic specialisation. In the $M R$, the agriculture is weakly developed even though $31 \%$ of the region's land is occupied by farmland, including $80 \%(82,312$ thousand hectares) of pastures and $0.01 \%(1,028.9$ thousand hectares) of sown area. Table 2 shows general information on agricultural production development in the region as of early 2018.
Table 2 shows the positive dynamics of the annual increase in the production of mainly livestock agricultural products in the MR, as well as a sustainable increase in the number of agricultural entities and PPF, where the latter produce more than half of the gross agricultural output of the region. This is not surprising, because, according to the statistics, depending on the sise, in the rural areas of the MR, there are predominantly households consisting of five or more people. It allows working in People's private farms (PPF) (Figure 3A). The in-depth study showed that more than half of all regional PPF were located in the Munaily (over 21 thousand units) and Beineu areas (over 12 thousand units) (Figure 3B). 


\begin{tabular}{|c|c|c|c|c|c|}
\hline & 2013 & 2014 & 2015 & 2016 & 2017 \\
\hline $\begin{array}{l}\text { 1. Gross Product of Crop Farming( } \mathrm{mln} \text {. } \\
\text { Tenge) }\end{array}$ & $1,169.7$ & $1,215.8$ & $2,046.5$ & $2,112.2$ & $2,775.6$ \\
\hline $\begin{array}{l}\text { 2. Gross Product of Cattle Breeding ( } \mathrm{mln} \text {. } \\
\text { Tenge) }\end{array}$ & $7,144.8$ & $7,839.8$ & $9,665.9$ & $10,331.7$ & $10,867.4$ \\
\hline $\begin{array}{l}\text { 3. Number of Agricultural Formations } \\
\text { (units) }\end{array}$ & 1,142 & 1,436 & 1,325 & 1,542 & 1,865 \\
\hline 4. People's Private Farms (PPF) (units) & 46,010 & 54,183 & 53,610 & 55,185 & 57,552 \\
\hline $\begin{array}{l}\text { 5. The Ratio of the PPF Products in the } \\
\text { Total Volume of Agricultural Products (\%) }\end{array}$ & 60.1 & 62.5 & 59.0 & 57.9 & 54.9 \\
\hline $\begin{array}{l}\text { 6. Average Nominal Wages of One } \\
\text { Agricultural Labour (Tenge) }\end{array}$ & 46,812 & 58,687 & 59,774 & 53,269 & 42,783 \\
\hline
\end{tabular}

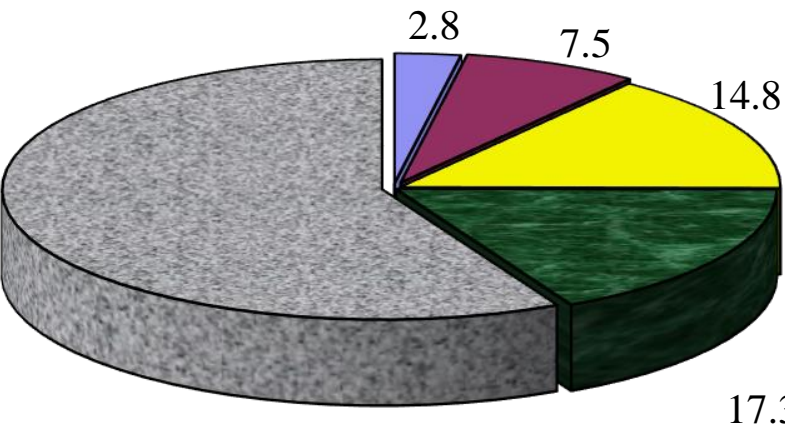

57.6

17.3
ㅁ1 person
口3 persons
$\square 5$ persons and more

A

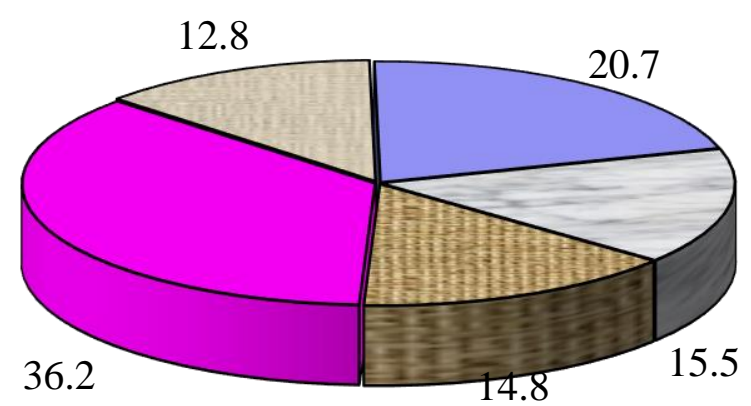

\begin{tabular}{|c|c|}
\hline DBeineu & 口Karakiyan \\
\hline $\begin{array}{l}\text { 口Mangystau } \\
\text { [Tupkaragan }\end{array}$ & ㅁMunaily \\
\hline
\end{tabular}

Figure 3: The Structure of Rural Households and Distribution of Personal Farms of the population in the Mangystau Region (MR) in 2018 (in per cent) Source: Compiled by the Authors

The most negative trend that certainly affects the well-being of the rural population of the region is the decline of the average nominal wages of agricultural labour over the last two years, as shown in Table 3. The average nominal wages of agricultural labour in the MR in 2017 happened to be not only 2.1 times lower $(42,783$ tenges) than the national average $(91,084$ tenges), but 10.5 times lower than the average wages of an employee working in the oil and gas industry in the MR (448,467 tenges). This state of affairs may increase social tension in society because it clearly reflects the inequality in the material wealth among employees working in different industries in the same region. In this regard, the dynamics of indicators characterising 
Table 4: Table 1 - Indicators Related to the Development of the Rural Social and Labour -Area in the Mangystau Region (MR) for $2013-2017$

\begin{tabular}{|l|c|c|c|c|c|}
\hline & 2013 & 2014 & 2015 & 2016 & 2017 \\
\hline Labour Force in the Rural Area (in thousands) & 124 & 110 & 134 & 139 & 147 \\
\hline Including Employed population & 116.2 & 103.9 & 126.5 & 131.9 & 140 \\
\hline Unemployment & 6.3 & 5.6 & 5.8 & 5.1 & 4.9 \\
\hline Including Young (15-24 years old) & 10.9 & 12.0 & 6.5 & 7.9 & 8.9 \\
\hline Long-term Unemployment & 5.5 & 13.2 & 6.5 & 7.9 & 8.4 \\
\hline $\begin{array}{l}\text { Average Monthly Income of the Household } \\
\text { Spent for the Consumption (in Tenge) }\end{array}$ & 32,147 & 35,229 & 35,095 & 38,810 & 39,771 \\
\hline
\end{tabular}

Sources: Compiled by the Authors Based on Socio-Economic Development of the Mangystau Region, 2018 and Socio-Economic Development of the Regions of the Republic of Kazakhstan, 2018

the state of the social and labour area of the rural areas of the MR were additionally analysed (Table 4). The analysis of Table 4 shows both positive and negative trends in the development of the rural labour market in the region. On the one hand, over recent years, there has been a sustainable increase in the number of employed and a reduction in the overall unemployment rate in rural areas of the MR. On the other hand, 5.

\begin{tabular}{|c|c|c|c|c|c|}
\hline No./Regions & 3 & 4 & 5 & 6 & 7 \\
\hline Natural Growth of the RP & 1,764 & 845 & 1,012 & 3,058 & 619 \\
\hline Net Migration & -247 & -362 & -272 & 5,427 & 1,879 \\
\hline $\begin{array}{l}\text { Number of Health Care Organisations } \\
\text { (HCO), units }\end{array}$ & 8 & 3 & 6 & 15 & 4 \\
\hline $\begin{array}{l}\text { Volume of Services Provided by HCO } \\
\text { (Thousand Tenge) }\end{array}$ & $1,726,128$ & 953,105 & 871,686 & $2,050,961$ & 664,432 \\
\hline As Calculated per One Resident & 25.3 & 25.6 & 22.6 & 13.4 & 22.7 \\
\hline Death Rate per 1,000 Persons & 4.33 & 3.31 & 4.1 & 3.23 & 4.25 \\
\hline $\begin{array}{l}\text { Number of Educational Organisations } \\
\text { (EO) (units) }\end{array}$ & 48 & 40 & 46 & 41 & 27 \\
\hline $\begin{array}{l}\text { Volume of Services Provided by EE } \\
\text { (Thousand Tenge) }\end{array}$ & $1,533,134$ & $1,507,700$ & $1,065,353$ & $1,861,620$ & 857,047 \\
\hline As Calculated per One Resident & 22.4 & 40,5 & 27,6 & 12,2 & 29,3 \\
\hline $\begin{array}{l}\text { New Housing Supply (sq.m. of the } \\
\text { Total Area) }\end{array}$ & 40,334 & 46,774 & 139,791 & 38,220 & 391,018 \\
\hline $\begin{array}{l}\text { Average Provision with Housing (APH) } \\
\text { (sq.m. per Person) }\end{array}$ & 23.0 & 19.7 & 18.5 & 27.3 & 23.0 \\
\hline Poverty Level (PL) (Tenge per Month) & 28,868 & 29,388 & 29,332 & 31,373 & 28,072 \\
\hline
\end{tabular}

Sources: Compiled by the Authors Based on Educational Services in the Mangystau Region, 2018; Health Care Services in the Mangystau Region, 2018 and Socio-economic Development of the Mangystau Region, 2018 such socially significant indicators as long-term and youth unemployment have worsened over the recent years, and the growth in consumer spending of households has not been supported by the increase in the wages. The statistical analysis also showed that among the MR rural areas, there was a certain differentiation in the levels of VSI objects provision, as shown in Table . 
According to the above data, in terms of the VSI development [the volume of services provided by health care organisations (HCO) and educational organisations (EO) per one resident], the most prosperous area of the MR is the largest (64.3 sq. km.) Karakiya Area with a population of about 37.2 thousand people (the administrative centre is the village of Kuryk, where there is a new seaport), and the least prosperous is the Munaily Area. To make it clearer, Figure 4 shows the comparative characteristics of the VSA and the VSI of these rural areas of the MR.

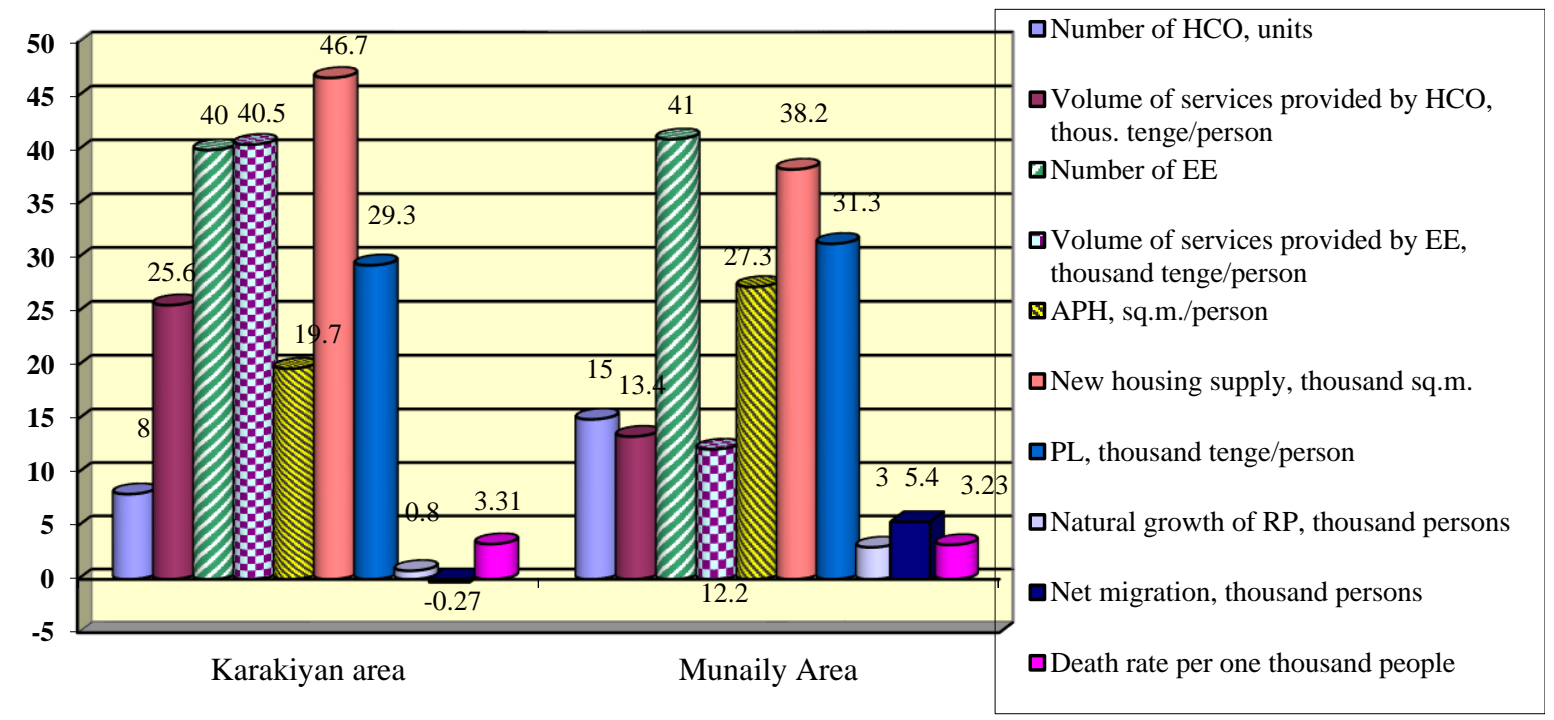

Figure 4: Indicators Related to the Development of the social area and infrastructure of villages of the Munaily and Karakiyan Areas in the Mangystau Region (MR) in 2017 Source:Compiled by the Authors

The survey of the rural residents in the MR that had been carried out in early 2018 and where 12.2 thousand persons participated made it possible to obtain additional information on the population's attitude to the work of local governments (district Akimats) and to determine the degree of rural residents' satisfaction with the VSI development by areas. Table 6 gives the overall picture of the most important survey results.

\begin{tabular}{|c|c|c|c|c|}
\hline Aspects of Rural Life & Proper & $\begin{array}{l}\text { Partially } \\
\text { Proper }\end{array}$ & Improper & In total \\
\hline Quality of School Education & 32.1 & 58.0 & 19.9 & 100.0 \\
\hline Quality of Medical Services & 22.2 & 64.1 & 13.7 & 100.0 \\
\hline Employment Opportunities & 29.7 & 27.2 & 43.1 & 100.0 \\
\hline State of Roads and Passenger Transportation & 13.6 & 50.5 & 35.9 & 100.0 \\
\hline Telecommunications & 66.7 & 19.7 & 13.6 & 100.0 \\
\hline $\begin{array}{l}\text { Work of Social Services (Help Provided to } \\
\text { Elderly and Disabled People, Multi-Member } \\
\text { Families, etc.) }\end{array}$ & 58.7 & 30.6 & 8.7 & 100.0 \\
\hline Work of Local Governments & 16.1 & 65.4 & 18.5 & 100.0 \\
\hline
\end{tabular}




\section{Discussion}

The study has shown that over the past years in the MR of the Republic of Kazakhstan the local and regional authorities have paid the increasing attention to the development of the rural social infrastructure, which is reflected in the growth of several social indicators. Positive trends included the increase in the rural population of the region by an average of $106 \%$ per year; a steadily increasing birth rate, and a reduction in the death rate, the growth of the number of private households of the population by $124 \%$ for the period 2013 - 2017, and the increase in the number of people employed in rural areas by $120 \%$ for the same period of time. For five years the level of rural unemployment in the region has decreased from $6.3 \%$ to $4.9 \%$, including among young people, from $10.9 \%$ to $8.9 \%$.

At the same time, the sociological survey has shown that only $16.1 \%$ of the rural population of the region are fully satisfied with the work of the governing bodies, the majority (65.4\%) are only partially satisfied, while $18.5 \%$ are dissatisfied with the work of the administration. The findings further reveal that $43.1 \%$ of the rural residents are not satisfied with the employment opportunities; nearly $36 \%$ were dissatisfied with thestate of roads and passenger transport, while about 20\% demonstrated dissatisfaction with the quality of school education. Nonetheless, the best reviews were obtained on the work of telephone communication where $67 \%$ were satisfied. Alongside, 59\% were satisfied with the work of social services.

The analysis of indicators related to developing the social infrastructure in areas of the MR has revealed that in 2017 the rural population of the Munaily Area obtained the medical assistance three times less in monetary value than the residents of the Karakiyan Area and two times less than the average residents of the MR areas. There is a similar situation in terms of educational services: while, on average, in the region 24 thousand tenge are spent per year per one rural resident; in the Munaily Area this amount is only 13.4 thousand tenge. At the same time, it is worth noting that this is the Munaily Area where there is the highest natural population growth, alongside positive and very high net migration; the lowest death rate of the population (3.23 against 4.0 average for areas), and the best level of housing provision (27.3 against 21 average for areas). The data obtained indicate the ambiguity of assessing VSI development only by using quantitative indicators. The results of the sociological survey have also shown that, despite considerable funding for rural $\mathrm{HCO}$, a considerable part (more than 64\%) of the rural residents are not completely satisfied with the quality of their services, and $13.7 \%$ are not satisfied at all.

\section{Conclusion}

The analysis of the efficiency of managing the rural social infrastructure involves the use of a considerable number of both quantitative and qualitative indicators. Its methodology has not been well established by now. It is obvious that it is necessary to continue and deepen studies in this area because only by assessing the efficiency of the measures taken, the management will be able to make the most rational decisions for improving the social area of the villages and wellbeing of their population.

\section{References}

Alashbaeva, A.N. (2013). Metodicheskiye podkhody k razrabotke analisa i otsenki programm razvitiya territoriy regionov Respubliki Kazakhstan [Methodical approaches to analising and assessing the programs on developing Kazakh territories]. Astana.

Balandin, D.A. (2014). Sovershenstvovaniye upravleniya ustoychivym razvitiyem selskikh territoriy [Improving the management of sustainable rural development]. Ekaterinburg, p. 169.

Bulkhairova, Zh.S., Imashova, Z.D., Nurtayeva, Zh.Sh., Taskinbaikisy, Zh., \& Yerkulova, G.S. (2018). The Current State of Affairs with Regard to the Effective Management of Human Capital in Agricultural. Enterprises Journal of Applied Economic Sciences, 13(4(58)), 1095-1100.

Diterich, M., \& Merzlov, A.V. (2013). Ustoychivoye razvitiye selskikh territoriy 
[Sustainable Rural Development]. Moscow: Ellis Lak, p. 680.

Drucker, P.F. (1987). A New Discipline. Success, p. 18.

Esimova, Sh.A. (2010). Effektivnost sistemy gosudarstvennogo upravleniya: teoriya i praktika [Efficiency of public administration: theory and practice]. Khmelnitsky: HUUP Publishing House.

Generalnaya skhema organisatsii territorii (GOST) Respubliki Kazakhstan [General scheme of organising the territory (GOST) of the

Republic of Kazakhstan]. (December 31, 2013). Approved by order of the Minister of Regional Development of the Republic of Kazakhstan No. 403/OD.

Kasenov, G.K. (2004). Upravleniye ustoychivym razvitiyem sotsialno-ekonomicheskoy infrastruktury selskikh naselennykh punktov ( $\mathrm{Na}$ materialakh Akmolinskoy Regioni)

[Management of sustainable development of social and economic infrastructure of rural settlements (Using the materials on the Akmola Region)]. Chelyabinsk, p. 139.

Kazakhstan v 2017 g: Statisticheskiy yezhegodnik [Kazakhstan in 2017: Statistical yearbook]. Retrieved August 29, 2019 from https://www.stat.gov.kz.

Kleimenov, D.S. (2016). Sovershenstvovaniye upravleniya razvitiyem selskikh territoriy [Improving the management of rural development]. Voronezh, p. 166.

Komarov, M.P. (2000). Infrastruktura regionov mira [Infrastructure the world regions]. Saint Petersburg: Publishing house of Mkhailov.

Kozlov, A.V., Yakovleva, O.A., \& Mindlin, Yu.B. (2018). Sostoyaniye i tendentsii razvitiya sotsialnoy infrastruktury selskikh territoriy v stranakh EAES [State and trends of social infrastructure development in rural areas in the EAEU countries]. Modern Science: Current Problems of Theory and Practice. Series: Economics and Law, 2, 31-36.

Monitoring razvitiya aula (sela) [Monitoring the aul (village) development]. (2018). Aktau: Statistical Collection.
Nukesheva, A.Zh. (2001). Organisatsiya i funktsionirovaniye proisvodstvennoy infrastruktury $v$ selskokhozyaystvennykh formirovaniyakh (na primere khozyaystvuyushchikh subyektov Akmolinskoy Regioni) [Organisation and functioning of the production infrastructure in agricultural formations (through the example of economic entities of the Akmola Region)]. Astana.

Serkov, A.F., Maslova, V.V., \& Chekalin, V.S. (2018). Ustoychivoye razvitiye i povyshenie konkurentosposobnosti selskogo khozyaystva Rossii v usloviyakh uglubleniya integratsii v EAES [Sustainable development and improving the competitiveness of Russian agriculture in the context of deepening the integration in the EAEU]. Moscow: Scientific Consultant, p. 320.

Sotsialno-ekonomicheskoye razvitiye Mangystauskoy Regioni [Socio-economic development of the Mangystau Region]. (2018). Aktau: Information and Analytical Magazine, p. 91.

Sotsialno-ekonomicheskoye razvitiye regionov Respubliki Kazakhstan [Socio-economic development of the regions of the Republic of Kazakhstan]. (2018). Astana: Statistical Collection.

Stukach, V.F., Grishaeva, E.A., Astashova, V.S., \& Pecevich, L.V. (2015). Infrastruktura:

rynochnyye instituty, sotsialnaya sfera sela, proisvodstvo [Infrastructure: market institutions, village social sphere, production]. Omsk: Publishing house of Stolypin Omsk State Agrarian University, p. 276.

Susura, D.A. (2012). Upravleniye mnogofunktsionalnoy selskoy ekonomikoy: ot tselepolaganiya do otsenki rezultatov [Managing a multifunctional rural economy: from goal setting to assessing results]. Moscow: University book, p. 126.

Uslugi obrazovaniya v Mangystauskoy oblasti [Educational services in the Mangystau Region]. (2018). Aktau: Statistical Bulletin.

Uslugi zdravookhraneniya v Mangystauskoy Regioni [Health care services in the Mangystau Region]. (2018). Aktau: Statistical Bulletin. 